\title{
Beetles (Coleoptera) of the Rogów region. Part III - carrion beetles (Silphidae)
}

\author{
Jerzy Borowski ${ }^{\star}$ \\ Department of Forest Protection and Ecology, Warsaw University of Life Sciences, SGGW, \\ ul. Nowoursynowska 159/34, 02-776 Warsaw, Poland \\ *E-mail address: jerzy_borowski@sggw.pl
}

\begin{abstract}
In the present, the third part of the series titled "Beetles (Coleoptera) of the Rogów region" presents a family of carrion beetles (Silphidae), as one of the better-known families of beetles occurring in the Rogów area. The faunistic data of presented species enriched by bionomical information.
\end{abstract}

Keywords: Insecta; Coleoptera; Silphidae; Rogów region; faunistic data; bionomy

\section{INTRODUCTION}

Until now from the Rogów region has been reported 6 species of carrion beetles (Gieysztor \& Pawłowicz 1938, Mokrzycki 2011, Byk \& al. 2013, Rutkiewicz \& al. 2013).

The following is a list of the species of carrion beetles that occur in the Rogów region. Almost all species have been collected by the author, and a small part of specimens comes from the collection of J. Dominik, A. Szujecki and S. Mazur. Specimens of evidence are in the collection of Department of Forest Protection and Ecology in Rogów. Names are taken from the Catalogue of Palearctic Coleoptera (Löbl \& Smetana 2004). All species have been identified or verified by the author of the work.

\section{RESULTS - REVIEW OF THE SPECIES}

\subsection{Dendroxena quadrimaculata (Scopoli, 1771)}

- Rogów, „Zimna Woda and Wilczy Dół” range, UTM: DC24, 24.V.1997, 1 ex., on rowan' flower; 03.V.2006, 1 ex., on herbs;

- Rogów, dendrological garden, UTM: DC24, 23.V.2003, 1 ex., on the lane.

For the first time in the Rogów region shown by Gieysztor \& Pawłowicz (1938). Not common species, appearing in greater numbers during the gradation of moths from the Geometridae family (species from the Operophtera Hübner and Erannis Hübner genera.

\subsection{Necrodes littoralis (Linnaeus, 1758)}

For the first time in the Rogów region shown by Mokrzycki (2011). 
- Rogów, „Zimna Woda and Wilczy Dół” range, UTM: DC24, 05.VI.1991, 1 ex., in the forest, the dead dog; 15.X.1999, 1 ex., under old pine, sifted; chicken.

- Rogów, „Górki” range, UTM: DC24, 13-14.V.1999, 2 exx., agricultural field, the dead

Quite common species usually found on carrion of larger animals.

\subsection{Oiceoptoma thoracicum (Linnaeus, 1758)}

- Rogów, „Zimna Woda and Wilczy Dół” range, UTM: DC24, 05.VI.1991, 2 exx., in the forest, the dead dog;

- Gutkowice, UTM: DC33, 03.IV.1999, 2exx., agricultural field, the dead chicken;

- Parcela Popień, „Popień” range, UTM: DC23, 29.V.1995, 1 ex., on the road.

For the first time in the Rogów region shown by Byk \& al. (2013). In the Rogów region very common species, collected on the dead small and big animals and slugs.

\subsection{Phosphuga atrata (Linnaeus, 1758)}

For the first time in the Rogów region shown by Mokrzycki (2011).

- Rogów, UTM: DC24, 1-31.VII.1963, 1 ex., leg. J. Dominik;

- Rogów, „Zimna Woda and Wilczy Dół” range, UTM: DC24, 20.X.1997, 1 ex., under bark of oak; Scots pine;

- Rogów, dendrological garden, UTM: DC24, 01.I.1998, 1 ex., under bark, old live

- Rogów, „Doliska” range, UTM: DC24, 20.II.1998, 5 exx., under bark of oak;

- Gutkowice, UTM: DC33, 01.X.1997, 1 ex., under bark of alder;

- Lipce, UTM: DC25, „Bukowiec” reserve, 12.XI.1997, 7 exx., under bark of beech.

In the Rogów area, this species is a commonest representative of the family. The easiest way to catch it during wintering, under a loose bark of trees.

\subsection{Silpha carinata Herbst, 1783}

- Rogów, dendrological garden, UTM: DC24, 1-30.VI.1998, 1 ex., Moericke trap; chicken.

- Rogów, „Górki” range, UTM: DC24, 12-13.V.1999, 3 exx., agricultural field, the dead

Quite common species usually found during the spring on carrion of larger animals.

\subsection{Silpha obscura Linnaeus, 1758}

- Gutkowice, UTM: DC33, 24.V.1999, 1 ex., and 24.VII.2007, 1 ex., on the road.

Rare species in the Rogów region. Specimens were found between agricultural fields and never seen on carrion.

\subsection{Silpha tristis Illiger, 1798} chicken;

- Rogów, „Górki” range, UTM: DC24, 13-15.V.1999, 3 exx., agricultural field, the dead

- Rogów, „Doliska” range, UTM: DC24, 02.IV.2011, 2 exx., in the ground; 15.IX.2011, 4 exx., the fox excrement;

- Rogów, UTM: DC24, 02.IX.2004, 1 ex., under stone; 20.VIII.2011, 1 ex., on the road. 
In the Rogów area most common species of the Silpha L. genus. Found in various environments, but usually outside the forest.

\subsection{Thanatophilus dispar Herbst, 1793}

- Rogów, dendrological garden, UTM: DC24, 23.IV.1999, 1 ex., on the road;

- Rogów, UTM: DC24, 2.IX.2005, 1 ex., forest edge; 28.VI.2007, 1 ex., on the road.

In the Rogów region very rare species, individually collected. Through 20 years of research in the area and use of various traps, caught only 3 specimens of this species.

\subsection{Thanatophilus rugosus (Linnaeus, 1758)}

- Rogów, „Zimna Woda and Wilczy Dół” range, UTM: DC24, 05.VI.1991, 1 ex., in the forest, the dead dog;

- Rogów, dendrological garden, UTM: DC24, 30.IV.1997, 1 ex., on herbs;

- Rogów, „Górki” range, UTM: DC24, 23.V.1995, 1 ex., cow bone;

- Gutkowice, UTM: DC33, 02.IV.1998, 4 exx., agricultural field, the dead chicken. animals.

Common species found in various environments, on the carrion of small and large

2.10. Thanatophilus sinuatus (Fabricius, 1775)

- Rogów, „Zimna Woda and Wilczy Dół” range, UTM: DC24, 05.VI.1991, 1 ex., in the forest, the dead dog;

- Rogów, „Górki” range, UTM: DC24, 23.V.1995, 2 exx., cow bone; 03.VIII.1997, 2 exx., owl pellet;

- Gutkowice, UTM: DC33, 28.VI.1997, 1 ex., cow bone; 03.IV.1999, 7 exx., agricultural field, the dead chicken.

For the first time in the Rogów region shown by Rutkiewicz \& al. (2013). Common species found in various environments, on carrion and dried excrements of small and large animals.

\subsection{Nicrophorus germanicus (Linnaeus, 1758)}

- Rogów, „Zimna Woda and Wilczy Dół” range, UTM: DC24, 06.VI.1954, 1 ex., leg et det. A. Szujecki.

A very rare species in the Rogów region, not observed since more than 60 years. The only specimen (male) are collected from the forest near the dendrological garden.

\subsection{Nicrophorus humator (Gleditsch, 1767)}

- Rogów, dendrological garden, UTM: DC24, 07.VIII.1997, 1 ex., on dead mouse; 1019.IV.1998, 7 exx., on dead mole;

- Gutkowice, UTM: DC33, 03.IV.1999, 1 ex., agricultural field, the dead chicken.

A very common species found in various environments, on the carrion of small and large animals. 
2.13. Nicrophorus interruptus Stephens, 1830

- Rogów, dendrological garden, UTM: DC24, 10.X.1995, 1 ex., indoor the building; 03.VII.1997, 1 ex., on dead sparrow.

In the Rogów region rarely caught. Specimen collected indoor the building, was found between marten excrements.

\subsection{Nicrophorus investigator Zetterstedt, 1824}

- Rogów, dendrological garden, UTM: DC24, 07.VIII.1951, 1 ex., leg. J. Dominik; 07.VIII.1997, 4 exx., on dead mouse; 03.VII.1997, 1 ex., on dead thrush; chicken.

- Rogów, „Górki” range, UTM: DC24, 16.V.1999, 3 exx., agricultural field, the dead

For the first time in the Rogów region shown by Byk \& al. (2013). Common in the Rogów region. Usually collected on dead small animals.

\subsection{Nicrophorus sepultor Charpentier, 1825}

- Rogów, dendrological garden, UTM: DC24, 01.VII.1997, 1 ex., on dead thrush.

A very rare species in the Rogów region. Through 20 years of research in the area and use of various traps, caught only 1 specimen of this species.

\subsection{Nicrophorus vespillo (Linnaeus, 1758)}

- Rogów, dendrological garden, UTM: DC24, 22.IV.1950, 1 ex., leg. J. Dominik;

- Rogów, „Zimna Woda and Wilczy Dół” range, UTM: DC24, 22.V.1950, 1 ex., leg. J. Dominik; 05.VI.1991, 1 ex., in the forest, the dead dog;

- Rogów, UTM: DC24, 1-10.V.1967, 1 ex., leg. S. Mazur, on dead hare;

- Gutkowice, UTM: DC33, 03.IV.1999, 1 ex., and 10.IV.1999, 3 exx., agricultural field, the dead chicken.

For the first time in the Rogów region shown by Byk \& al. (2013). Common species found on spring in various environments, on the carrion of small and large animals.

\subsection{Nicrophorus vespilloides Herbst, 1783}

- Rogów, dendrological garden, UTM: DC24, 03.V.1999, 1 ex., on the road;

- Rogów, „Zimna Woda and Wilczy Dół” range, UTM: DC24, 13.IX.1949, 1 ex., leg. J. Dominik;

- Gutkowice, UTM: DC33, 01.X.1997, 1 ex., the dog excrement; chicken.

- Rogów, „Górki” range, UTM: DC24, 10-20.V.1999, 5 exx., agricultural field, the dead

For the first time in the Rogów region shown by Mokrzycki (2011). In the Rogów area most common species of the Nicrophorus F. genus. Found in various environments, on carrion and dried excrements of small and large animals.

2.18. Nicrophorus vestigator Herschel, 1807 chicken;

- Rogów, „Górki” range, UTM: DC24, 10-18.V.1999, 4 exx., agricultural field, the dead 
- Gutkowice, UTM: DC33, 02.IV.1998 1 ex., and 3-10.IV.1999, 3 exx., agricultural field, the dead chicken.

Quite rare species, collected on spring, on xerothermic localities.

\section{CONCLUSIONS}

The carrion beetles as ladybirds (Borowski 2015) are one of the better-known families of beetles in the Rogów region. There are 18 known species representing approx. $70 \%$ of all species in our country. Due to the specific biology of development (on dead animals or their parts) habitat, is of secondary importance, and usually on the carrion we can find several species simultaneously. Given the zoogeographical requirements of some species which are not caught yet from the Rogów area, it is possible to catch two or three more.

\section{Acknowledgements}

I would like to thank Prof. Andrzej Szujecki and Prof. S. Mazur for the material used in this work.

\section{References}

[1] Borowski J. 2015. Beetles (Coleoptera) of the Rogów region. Part II - ladybirds (Coccinellidae). International Letters of Natural Sciences, 7(2015): 90-101.

[2] Byk A., Borowski J., Mazur S., Mokrzycki T., Rutkiewicz A. 2013. Waloryzacja lasów Leśnego Kompleksu Promocyjnego „Lasy Spalsko-Rogowskie” na podstawie zgrupowań chrząszczy saproksylicznych. Studia i Materiały CEPL w Rogowie, 35(2): 82-128.

[3] Gieysztor M., Pawłowicz J. 1938. Spostrzeżenia nad masowym wystąpieniem gatunków z rodzajów Erannis i Operophtera (Lep.) w lesie dębowym w Rogowie. Polskie Pismo Entomologiczne, 16-17: 16-36.

[4] Löbl I., Smetana A. (ed.). 2004. Catalogue of Palearctic Coleoptera. Vol. 2. Stenstrup: Apollo Books, 942 pp.

[5] Mokrzycki T. 2011. Zgrupowania saproksylicznych chrząszczy (Coleoptera) w pniakach wybranych gatunków drzew - studium porównawcze. Wydawnictwo SGGW, Warszawa, $135 \mathrm{pp}$.

[6] Rutkiewicz A., Borowski J., Byk A., Mokrzycki T. 2013. Waloryzacja lasów Leśnego Kompleksu Promocyjnego „Lasy Spalsko-Rogowskie” na podstawie zgrupowań chrząszczy saproksylicznych powierzchni pni drzew. Studia i Materiały CEPL w Rogowie, 35(2): 129-159. 